\title{
Enhancing methane yield from crude glycerol anaerobic digestion by coupling with ultrasound or $A$. niger/E. coli biodegradation
}

\author{
Larissa O. Paulista $^{1}$ • Rui A. R. Boaventura ${ }^{1}$ - Vítor J. P. Vilar ${ }^{1}$. Alexei L. N. Pinheiro ${ }^{2} \cdot$ Ramiro J. E. Martins $^{1,3}$ (D)
}

Received: 20 May 2019 / Accepted: 11 October 2019

(C) Springer-Verlag GmbH Germany, part of Springer Nature 2019

\begin{abstract}
Anaerobic digestion of crude glycerol from biodiesel production is a feasible way for methane production. However, crude glycerol (CG) contains impurities, such as long-chain fatty acids (LCFA) that can inhibit methanogenic microorganisms. Ultrasound promotes the hydrolysis of LCFA and deagglomerates the microorganisms in biological flocs. Furthermore, Aspergillus niger and Escherichia coli produce lipases capable of degrading LCFA. This study aims at improving the methane yield from anaerobic digestion by coupling with ultrasound or $E$. coli/A. niger biodegradation. The effect of the different treatments was first assessed in a perfectly mixed batch reactor (PMBR), using diluted CG at concentrations of $0.2 \%, 1.7 \%$, and $3.2 \%(\mathrm{v} / \mathrm{v})$. Later, the best conditions were replicated in an upflow anaerobic sludge blanket (UASB) reactor to simulate fullscale practical applications. Experiments in the PMBR showed that ultrasound or A. niger biodegradation steps improved methane yield up to $11 \%$ for $0.2 \% \mathrm{CG}$ and $99 \%$ for $1.7 \% \mathrm{CG}$, respectively. CG biodegradation by $E$. coli inhibited the subsequent anaerobic digestion for all concentrations tested. Using a UASB digester, ultrasonic treatment of CG led to an average increase of $29 \%$ in methane production. The application of ultrasound led to a lower accumulation of propionic acid in the digested material and increased biogas production. On the other hand, an average $77 \%$ increase in methane production was achieved using a preliminary CG biodegradation step by $A$. niger, when operated at a loading rate of $2.9 \mathrm{~kg} \mathrm{COD} \mathrm{m}^{-3} \mathrm{day}^{-1}$. Under these conditions, an energy gain of $0.48 \mathrm{kWh}$ day $^{-1}$, with the production of the $0.434 \mathrm{~m}^{3} \mathrm{CH}_{4} \mathrm{~kg}^{-1} \mathrm{COD}_{\text {removal }}$ and $0.573 \mathrm{~m}^{3} \mathrm{CH}_{4}$ $\mathrm{kg}^{-1} \mathrm{VS}$, and a biogas quality of $73 \%$ in methane were obtained. The digested material was analyzed for the detection and quantification of added-value by-products in order to obtain a broad assessment of the CG valorization through anaerobic digestion. In some experiments, propionic and oxalic acid were detected. However, the accumulation of propionic caused the inhibition of the acetogenic and methanogenic microorganisms.
\end{abstract}

Keywords Crude Glycerol · Biogas · Ultrasound · Biodegradation · Batch · UASB

Responsible editor: Gerald Thouand

Ramiro J. E. Martins

rmartins@ipb.pt

1 Laboratory of Separation and Reaction Engineering-Laboratory of Catalysis and Materials (LSRE-LCM), Department of Chemical Engineering, Faculty of Engineering, University of Porto, Rua Dr. Roberto Frias, 4200-465 Porto, Portugal

2 Departamento de Química, Universidade Tecnológica Federal do Paraná, Campus Londrina, Av. dos Pioneiros 3131, Londrina 86036-370, Brazil

3 Department of Chemical and Biological Technology, Superior School of Technology, Polytechnic Institute of Bragança, Campus de Santa Apolónia, 5300-253 Bragança, Portugal

\section{Introduction}

The most common process of biodiesel production is transesterification: an alcohol (methanol) is added to a vegetable or animal oil, which forms esters (methyl ester) and glycerol by the action of a catalyst (sodium hydroxide or potassium hydroxide). The crude glycerol (CG) generated as byproduct $(10 \mathrm{wt} \%)$ can be used in a wide range of industrial processes (Almena and Martín 2015) but requires complex purification processes depending on the use and destination. The glycerol content in CG ranges from 23 to $87 \%$ (Dobrowolski et al. 2016; Hu et al. 2012), which determines the final price and economic viability for use in other processes. In addition, increased industrial production of biodiesel has led to a surplus of glycerol, which causes a commercial 
devaluation and an impact on the price of biodiesel. In this context, other forms of glycerol valorization became interesting and important both economically and environmentally (Leoneti et al. 2012), such as catalytic pyrolysis for the synthesis of bio-based benzene, toluene, and xylenes (He et al. 2018); catalytic auto-thermal reforming (Afabor et al. 2017; He et al. 2018); and electrochemical reforming (Marshall and Haverkamp 2008) for hydrogen production. Biotransformation of CG to compounds with greater added economic value like bioethanol, poly 3-hydroxybutyrate, malic acid, propionic acid, and citric acid by action of microorganisms has also been considered (Iyyappan et al. 2018; Papanikolaou et al. 2008; Shah et al. 2014; Zhang and Yang 2009), including the anaerobic co-digestion of cattle manure and wastewater sludge with $\mathrm{CG}$ for the production of methane and hydrogen, respectively (Castrillón et al. 2013; Pachapur et al. 2016). However, anaerobic digestion of the $C G$ presents some hindrances. The use of high glycerol loads may cause the accumulation of volatile fatty acids and a decrease in $\mathrm{pH}$, which ultimately leads to the inhibition of methanogenic microorganisms (Razaviarani and Buchanan 2015; Silva et al. 2018). This limits the glycerol concentration in the feed to values below $3 \%(\mathrm{v} / \mathrm{v})$. In fact, lower methane yields have been reported for higher concentrations (López et al. 2009). Two strategies have been devised to overcome this issue: the anaerobic co-digestion of CG with suitable amounts of agroindustry waste, urban solid wastes, or biological sludge from wastewater treatment plants (Pachapur et al. 2016; Razaviarani and Buchanan 2015) and the use of two reactors in series, the first one providing the breakdown of the molecule in the hydrolysis and acidogenesis phases and the second one for biogas production, just as favorable conditions for acetogenic and methanogenic microorganisms (Luo et al. 2011).

Another hindrance to CG anaerobic digestion is the presence of remnants of the long-chain fatty acids (LCFA), which, despite their biodegradability, may adhere to the cell membranes of the microorganisms and block the passage of nutrients. An alternative to reduce the negative effect of the LCFA is the use of microorganisms capable of degrading glycerol and of producing lipases, such as Aspergillus niger, Escherichia coli, and Yarrowia lipolytica (Dobrowolski et al. 2016; Iyyappan et al. 2018; Shah et al. 2014). Literature reports high yields of added-value products from fermentation of CG by pure cultures of these microorganisms like hydrogen, ethanol, 3-propanediol, oxalic acid, and citric acid (Chatzifragkou and Papanikolaou 2012; Przystałowska et al. 2015). A particularly interesting feature of A. niger and $Y$. lipolytica cultures in media containing CG is that they can withstand significantly high amounts of CG without growth inhibition. The presence of LCFA also decreases the density of the biomass and hastens its way up out of the reactor. This problem could be addressed by the use of ultrasound treatment. Sonication can increase the contact between microorganisms and feed whilst keeping the LFCA well emulsified and can promote the deagglomeration of the microorganisms as well (Weemaes and Verstraete 1998).

Therefore, the main goal of this study was to evaluate the effect of the CG solution treatment by ultrasound or E. coli/ A. niger biodegradation, on the production of methane by anaerobic digestion. Ultrasound can improve CG dispersion in the feed solution and make it more available to microorganisms. A. niger and E. coli could aerobically degrade CG, releasing lipases to break the LCFA. The present work also intends to select the type of treatment (ultrasound/biodegradation) required as a function of $C G$ feed concentration. The effects of the ultrasound treatment time and CG concentration on the methane yields were first evaluated in a perfectly mixed batch reactor, and subsequently the conditions leading to higher methane production were replicated in an upflow anaerobic sludge blanket (UASB) reactor. The digested material was also analyzed for the detection and quantification of added-value by-products in order to obtain a broad assessment of the $\mathrm{CG}$ valorization through anaerobic digestion.

\section{Materials and methods}

\section{Physicochemical parameters and product analyses}

Most parameters were determined according to Standard Methods for the Examination of Water and Wastewater (Apha 1998): pH by method 4500, alkalinity by method 2320-B, solid analysis by method 2540 , chemical oxygen demand (COD) by method 5220-D, and total phosphorus $\left(\mathrm{P}_{\text {total }}\right)$ by method 4500-P.E. Volatile fatty acid (VFA) analysis was performed as described elsewhere (Buchauer 1998).

The carboxylic acids produced in the anaerobic digestion of CG were determined by high-performance liquid chromatography (HPLC) using a Hitachi ELITE Lachrom HPLC, equipped with a DAD L-2455 d, RezexTM ROA-Organic Acid $\mathrm{H}^{+}$column (8\%), DAD detector at $210 \mathrm{~nm}$, and $10-\mu \mathrm{L}$ loop and operating in isocratic mode $(0.005 \mathrm{~N}$ sulfuric acid as eluent) at a flow rate of $0.5 \mathrm{~mL} \mathrm{~min}^{-1}$.

\section{Crude glycerol and biological sludge}

The crude glycerol was obtained from a biodiesel pilot plant using vegetable oil as a raw material, located in ESTiG Polytechnic Institute of Bragança (IPB), Portugal. The physical-chemical characteristics of crude CG are shown in Table 1.

The anaerobic biological sludge used in all experiments was kindly supplied by the Vila Real (Portugal) Wastewater Treatment Plant (AD-VR), as collected directly from the anaerobic digester. The sludge presented a chemical oxygen 
Table 1 Physical-chemical characteristics of crude glycerol (CG)

\begin{tabular}{|c|c|c|c|}
\hline Parameter & Value & Values of literature & References \\
\hline $\mathrm{pH}$ & 8.4 & $5.8-8.8$ & (Panpong et al. 2014, Serrano et al. 2014) \\
\hline $\operatorname{COD}\left(\mathrm{g} \mathrm{L}^{-1}\right)$ & 1808 & $1200-1760$ & (Panpong et al. 2014, Serrano et al. 2014) \\
\hline $\mathrm{TS}\left(\mathrm{g} \mathrm{L}^{-1}\right)$ & 462 & $277-969$ & (Panpong et al. 2014, Razaviarani and Buchanan 2015) \\
\hline $\mathrm{FS}\left(\mathrm{g} \mathrm{L}^{-1}\right)$ & 36 & $2-11$ & (Serrano et al. 2014, Silvestre et al. 2015) \\
\hline $\operatorname{VS}\left(\mathrm{g} \mathrm{L}^{-1}\right)$ & 426 & $240-924$ & (Razaviarani and Buchanan 2015, Silvestre et al. 2015) \\
\hline $\operatorname{TDS}\left(\mathrm{g} \mathrm{L}^{-1}\right)$ & 456 & $302-590$ & (Nuchdang and Phalakornkule 2012) \\
\hline $\operatorname{TSS}\left(\mathrm{g} \mathrm{L}^{-1}\right)$ & 5.8 & $33.5-192$ & $\begin{array}{l}\text { (Nuchdang and Phalakornkule 2012, Razaviarani } \\
\text { and Buchanan 2015) }\end{array}$ \\
\hline $\operatorname{VSS}\left(\mathrm{g} \mathrm{L}^{-1}\right)$ & 5.3 & $8.3-28.3$ & (Nuchdang and Phalakornkule 2012) \\
\hline $\mathrm{P}_{\text {total }}\left(\mathrm{mg} \mathrm{L}^{-1}\right)$ & 0.2 & $0.1-72.9$ & $\begin{array}{l}\text { (Nuchdang and Phalakornkule 2012, } \\
\text { Panpong et al. 2014, Serrano et al. 2014) }\end{array}$ \\
\hline VFA $\left(\mathrm{g} \mathrm{L}^{-1}\right)$ & 9.7 & 6.7 & (Panpong et al. 2014) \\
\hline Density $\left(\mathrm{kg} \mathrm{m}^{-3}\right)$ & 1022 & $1052-1200$ & (Hutňan et al. 2013, Serrano et al. 2014) \\
\hline
\end{tabular}

$C O D$, chemical oxygen demand; $T S$, total solids; $F S$, fixed solid; $V S$, volatile solids; $T D S$, total dissolved solids; $T S S$, total suspended solids; VSS, volatile suspended solids; $P_{\text {total }}$, total phosphorus; VFA, volatile fatty acids demand (COD) of $32.1 \mathrm{~g} \mathrm{~L}^{-1}$ and a volatile-to-total solid ratio (VS/TS) of 0.65 close to the values recommended as suitable for good performance of the bioreactor Al-Jamal and Mahmoud (2009).

\section{Perfectly mixed batch reactor}

The assays were performed in a 500-mL capacity perfectly mixed batch reactor, as depicted in Fig. 1I, filled with biological sludge + substrate $(300 \mathrm{~mL}$ total volume). The substrate consisted of diluted CG at concentrations of $0.2 \%, 1.7 \%$, and $3.2 \%(\mathrm{v} / \mathrm{v})$ with appropriate amounts of potassium nitrate (C:N of 25:1), disodium phosphate (C:P of 120:1), and sodium bicarbonate $\left(2 \mathrm{~g} \mathrm{~L}^{-1}\right)$ as nutrients. The $\mathrm{COD}_{\text {glycerol }} /$ $\mathrm{COD}_{\text {total }}$ in the mixture of sludge and glycerol were 0.10 , 0.49 , and 0.65 for the $0.2 \%, 1.7 \%$, and $3.2 \%$ (v/v) CG concentration, respectively. The temperature was controlled within $35-40{ }^{\circ} \mathrm{C}$.
The volume of biogas generated and the methane content in the biogas were continuously monitored by a Milligascounter (Ritter) and a methane sensor (Blue Sens), respectively. COD and solid (volatile and total) analyses were performed after 15 and 30 days of operation. Carboxylic acids were determined in the digestate at the end of the assays.

\section{Biological and physical treatments}

Table 2 presents the experimental conditions used to assess the effect of physical (ultrasound) and biological (biodegradation by E. coli or A. niger) treatments on CG. The substrate (0.6, 5.1 , and $9.6 \mathrm{~mL}$ ) was added to the biological sludge up to 300 $\mathrm{mL}$, which corresponds to the concentrations of $0.2 \%, 1.7 \%$, and $3.2 \%(\mathrm{v} / \mathrm{v})$.

For the physical treatment (Fig. 1II), ultrasound was applied to the mixture of sludge and substrate $(300 \mathrm{~mL})$ by immersing the digesters in an ultrasonic bath (Selecta,

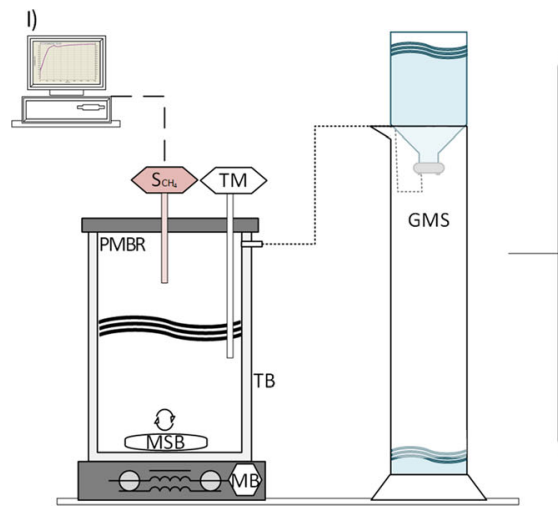

Fig. 1 The perfectly mixed batch reactor (PMBR) and the methane production monitoring system (I), physical treatment (II), and biological treatment (III). $\mathrm{S}_{\mathrm{CH} 4}$, methane sensor (Blue Sens); GMS, gas measuring system; MSB, magnetic stir bar; MS, magnetic bar; TB, thermal blanket;

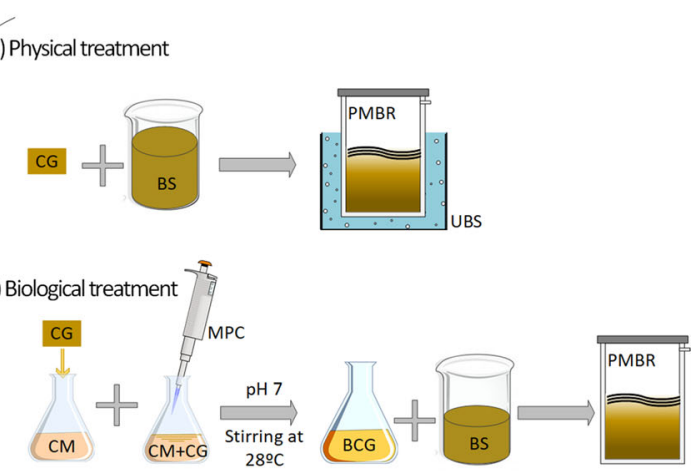

TM, temperature meter; CG, crude glycerol; CM, culture medium; MPC, microorganism pure culture; BCG, biodegraded crude glycerol; BS, biological sludge; UBS, ultrasonic bath sonicator 
Table 2 Treatment conditions in the assays conducted in the perfectly mixed batch reactor

\begin{tabular}{|c|c|c|c|}
\hline Experiment & Crude glycerol concentration $(\%)$ & Treatment & Name \\
\hline \multirow[t]{3}{*}{ Anaerobic digestion (control) } & 0.2 & - & 1 \\
\hline & 1.7 & - & 2 \\
\hline & 3.2 & - & 3 \\
\hline \multirow[t]{5}{*}{ Anaerobic digestion coupled with ultrasound (one time per day)* } & 0.2 & $3 \mathrm{~h} * *$ & $1 \mathrm{~A}$ \\
\hline & 0.2 & $15 \mathrm{~h}$ & $1 \mathrm{~B}$ \\
\hline & 3.2 & $3 \mathrm{~h}$ & $3 \mathrm{~A}$ \\
\hline & 3.2 & $15 \mathrm{~h}$ & 3B \\
\hline & 1.7 & $9 \mathrm{~h}$ & $2 \mathrm{C}$ \\
\hline \multirow[t]{6}{*}{ Anaerobic digestion after $\mathrm{CG}$ aerobic biodegradation } & 0.2 & A. niger & $1-1$ \\
\hline & 0.2 & E. coli & $1-2$ \\
\hline & 1.7 & A. niger & $2-1$ \\
\hline & 1.7 & E.coli & $2-2$ \\
\hline & 3.2 & A. niger & $3-1$ \\
\hline & 3.2 & E.coli & $3-2$ \\
\hline
\end{tabular}

*The ultrasound treatment was applied to the reactor during $1 \mathrm{~h}$ per day until the mentioned treatment time was attained; ${ }^{* *}$ The ultrasound treatment was applied during $1 \mathrm{~h}$ per day for only the first 3 days of anaerobic digestion, corresponding to a total ultrasound treatment time of $3 \mathrm{~h}$

$9 \mathrm{~L}, 40 \mathrm{kHz}, 200 \mathrm{~W})$ for $1 \mathrm{~h}$ every day. This process was repeated along the anaerobic digestion until achieving the total time indicated in Table 2. The temperature was controlled by adding ice to the ultrasonic water.

For the biological treatment (Fig. 1III), the same amounts of substrate were added to $100 \mathrm{~mL}$ of culture medium consisting of $1 \%$ yeast extract in $200 \mathrm{mM}$ TrisHCL. $20 \mu \mathrm{L}$ of a pure culture of Aspergillus niger (TCS Biosciences disc MM 94 number 16404) or Escherichia coli (disc ATCC 25922) were added to the culture medium. The solutions were maintained under stirring at $\mathrm{pH}$ 7.5 and $28{ }^{\circ} \mathrm{C}$ for a period of 7 days for A. niger and 2 days for $E$. coli. Then, $200 \mathrm{~mL}$ of the biological sludge was added to get a total volume of $300 \mathrm{~mL}$.

\section{Upflow anaerobic sludge blanket}

The UASB reactor with 16.5 -L working volume consisted of two PVC pipes with a nominal diameter of $10 \mathrm{~cm}$ connected in a "Y" shape, as depicted in Fig. 2. The vertical tube was $185 \mathrm{~cm}$ long (153 cm of useful height) and the second tube at an angle of $45^{\circ}$ was $86 \mathrm{~cm}$ long (57-cm working height). The temperature was kept around $40{ }^{\circ} \mathrm{C}$. The reactor was fed at 2 $\mathrm{mL} \min ^{-1}$ by a pump working for 15 min alternately with 15 min time interval resulting in a feed rate of $1.44 \mathrm{~L} \mathrm{day}^{-1}$ and a hydraulic retention time (HRT) of 11.5 days. To increase the concentration of biomass in the reactor, the sludge settled in a decanter was pumped back into the reactor four times a day for $15 \mathrm{~min}$ at a $16 \mathrm{~mL} \mathrm{~min}^{-1}$ flow rate.

Initially, $13 \mathrm{~L}$ of the sludge from the $\mathrm{AD}-\mathrm{VR}$ was added to the UASB reactor. Then, an adaptation phase of anaerobic microorganisms was started by adding $200 \mathrm{mg} \mathrm{L}^{-1}$ of methanol in the first day and $100 \mathrm{mg} \mathrm{L}^{-1}$ of methanol $+100 \mathrm{mg} \mathrm{L}^{-1}$ of CG in the second day. After the adaptation period, the UASB was fed as follows: (A) $0.4 \mathrm{~kg} \mathrm{COD} \mathrm{m}^{-3}$ day $^{-1}$ (weeks 1-3); (B) $0.4 \mathrm{~kg} \mathrm{COD} \mathrm{m}^{-3}$ day $^{-1}+15$-h ultrasound (weeks 4-5); (C) $2.9 \mathrm{~kg} \mathrm{COD} \mathrm{m}^{-3}$ day $^{-1}$ (weeks 6-8); (D) $2.9 \mathrm{~kg} \mathrm{COD} \mathrm{m}^{-3}$ day $^{-1}+$ A. niger treatment (weeks 9-10).

For the ultrasound/anaerobic digestion-coupled system, operated during weeks 4 and 5 , a concentrated feed solution ( $5 \mathrm{~L}$ of a $11.6 \mathrm{~kg}$ COD solution, i.e., $2.32 \mathrm{~kg}$ COD L $\mathrm{L}^{-1}$ ) was placed in the ultrasonic bath (Selecta, 9 $\mathrm{L}, 40 \mathrm{kHz}, 200 \mathrm{~W}$ ) for $15 \mathrm{~h}$ and then diluted before feeding the UASB anaerobic reactor at $1.44 \mathrm{~L} \mathrm{day}^{-1}$. In this case, unlike the batch reactor experiments, the sludge was not subject to ultrasound treatment.

For the A. niger/anaerobic digestion-coupled system, operated between weeks 9 and 10, an aerobic reactor (3.7-L capacity) was installed upstream from the UASB reactor, operating at $150 \mathrm{~L} \mathrm{~h}^{-1}$ air injection (Aqual El 150 pump, $2.5-\mathrm{W}$ power). It was started with the addition of $3.5 \mathrm{~L}$ of the culture medium (1\% yeast extract in $200 \mathrm{mM}$ Tris-HCL) used in the batch reactor and $0.25 \mathrm{~mL}$ of pure A. niger culture for a period of 7 days. Afterwards, the outlet of the aerobic biological reactor was used as the feed stream of the UASB reactor.

Temperature, $\mathrm{pH}$, methane concentration, and biogas production were monitored every day. Samples were collected every week at the reactor inlet, from inside the reactor, and at the digested liquid outlet from the decanter for COD, $\mathrm{P}_{\text {total }}$, TS, and VS analyses. 
Fig. 2 The upflow anaerobic sludge blanket reactor (UASB) apparatus. CG, crude glycerol; $\mathrm{S}_{\mathrm{CH} 4}$, methane sensor (Blue Sens); GMS, gas measuring system; HS, heating system; TM, temperature meter; PP, peristaltic pump; VCS, valve to collect sample; DC, decanter in continuous; DL, digested liquid; PCAR, pure culture aerobic reactor; UBS, ultrasonic bath sonicator; asterisk, additional to the system

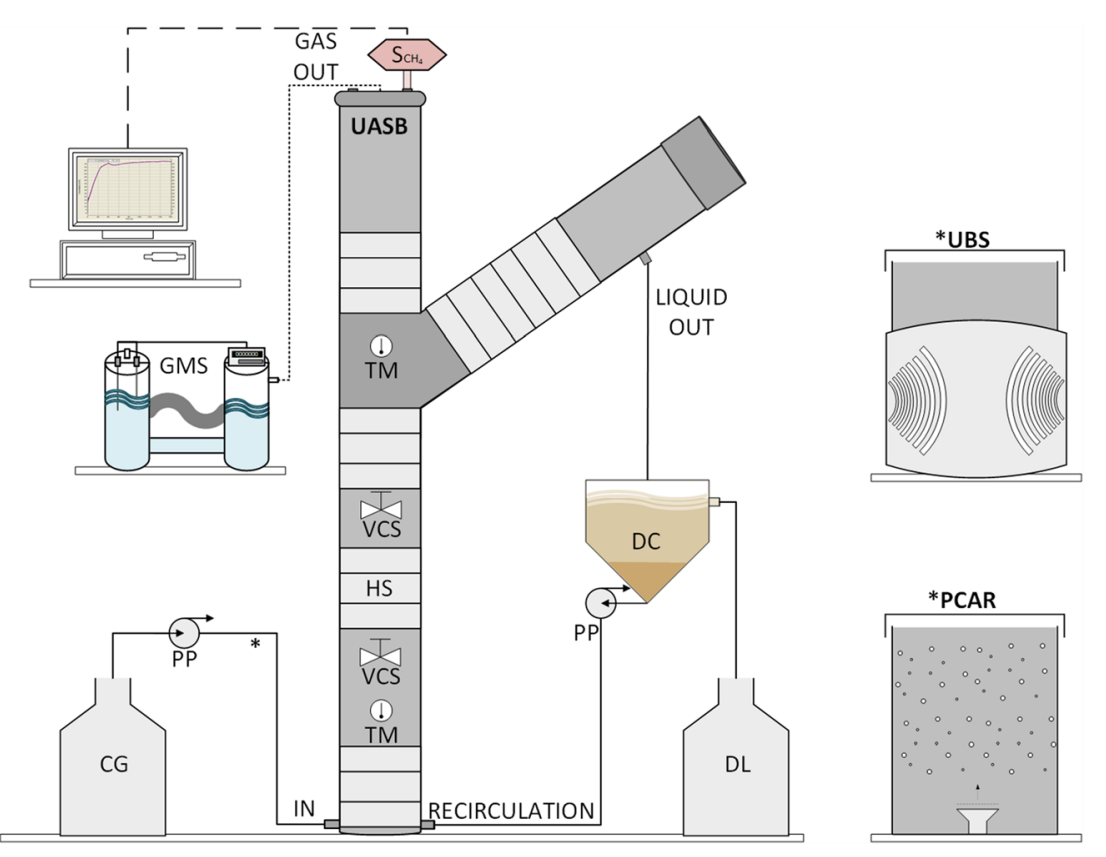

\section{Results and discussion}

\section{Perfectly mixed batch reactor}

\section{Ultrasound}

Figure 3I presents the cumulative methane and biogas production as a function of time for $\mathrm{CG}$ anaerobic digestion for different concentrations in the feed and ultrasound treatment times. High methane yields above $250 \mathrm{~mL}$ were observed only for the lower $\mathrm{CG}$ concentration of $0.2 \%(\mathrm{v} / \mathrm{v})$, indicating strong inhibition of the methanogenic microorganisms for higher concentrations. For the 1.7 and $3.2 \%$ CG concentration $(\mathrm{v} / \mathrm{v})$, methane production was always below $16 \mathrm{~mL}$, and although the 9-h ultrasound treatment improves the methane yield for the $1.7 \%$ CG concentration (v/v), its benign effect does not compensate for the inhibitory effect of the high $\mathrm{CG}$ load. The biogas production ranged from 300 to $800 \mathrm{~mL}$ on average for all experiments except for the $\mathrm{CG}$ concentration of $3.2 \%(\mathrm{v} / \mathrm{v})$ with $15-\mathrm{h}$ ultrasound treatment, which produced only $200 \mathrm{~mL}$ of biogas, mostly in the last days.

In the experiments with the ultrasonic treatment, it was observed an increase of the VS in the 15 days of experiment (Fig 3b), which was not observed in the controls (experiments 1,2, and 3). The increase in the amount of VS in the anaerobic medium can be explained by the incorporation of water molecules into compounds in the hydrolysis, which must result in adducts with increased mass. Another possibility, under anaerobic conditions, would be the incorporation of water molecules into the $\beta$-oxidation cycle of the LCFA. However, this latter process would be followed by hydrogen production and thus a consequential decrease in the COD, which was not observed in the experiments. The ultrasound treatment effectively enhances the hydrolysis of the substrate molecules (Mulinari et al. 2017) whereas promoting the disaggregation of the biological sludge and the long-chain molecule colloidal particles.

CG has a complex matrix composed of oils and fatty acids. Notice that the increase in the VS content is observed for the highest $\mathrm{CG}$ concentration in assay $3 \mathrm{~A}$, thus indicating that the $\mathrm{CG}$ is the major source of the long-chain organic compounds. In this way, its degradation was estimated through COD removal (Fig. 3III). The average COD consumption was very close for the three concentrations of CG: $25 \pm 2 \mathrm{~g} \mathrm{~L}^{-1}, 25 \pm 7 \mathrm{~g}$ $\mathrm{L}^{-1}$, and $29 \pm 9 \mathrm{~g} \mathrm{~L}^{-1}$ for $0.2 \%, 1.7 \%$, and $3.2 \%$ of $\mathrm{CG}$ concentration (v/v), respectively. The COD decrease is associated with the generation of biogas $\left(\mathrm{CO}_{2}, \mathrm{CH}_{4}\right.$, and $\left.\mathrm{H}_{2} \mathrm{~S}\right)$.

For the assays with a CG concentration of $0.2 \%(\mathrm{v} / \mathrm{v})$, the initial COD varied between 35.5 and $35.7 \mathrm{~g} \mathrm{~L}^{-1}, 10 \%$ of this total corresponding to the addition of CG (Fig. 3I). For experiments $1,1 \mathrm{~A}$, and $1 \mathrm{~B}$, there was only the production of oxalic acid in concentrations of $0.25 \mathrm{~g} \mathrm{~L}^{-1}, 0.08 \mathrm{~g} \mathrm{~L}^{-1}$, and $0.07 \mathrm{~g} \mathrm{~L}^{-1}$, respectively (Fig. 4). The application of ultrasound for $3 \mathrm{~h}$ was not enough to cause a positive effect on methane production for this CG concentration. However, the application of ultrasound for $15 \mathrm{~h}$ increased the volume of methane produced in relation to control by $11 \%$ and the following results were achieved: $391 \mathrm{~mL}$ of methane production, $0.047 \mathrm{~L} \mathrm{CH}_{4} \mathrm{~g}^{-1}$ COD removed, and $0.652 \mathrm{~L} \mathrm{CH}_{4} \mathrm{~mL}^{-1} \mathrm{CG}$ and $77 \%$ of methane in the biogas.

For the treatments with $1.7 \%$ of $\mathrm{CG}(\mathrm{v} / \mathrm{v})$ (Fig. 3II), the initial COD concentration varied between 62.1 and $62.2 \mathrm{~g}$ $\mathrm{L}^{-1}$, half of this value corresponding to $\mathrm{CG}$ and the remainder to the biological sludge. The application of ultrasound for $9 \mathrm{~h}$ 

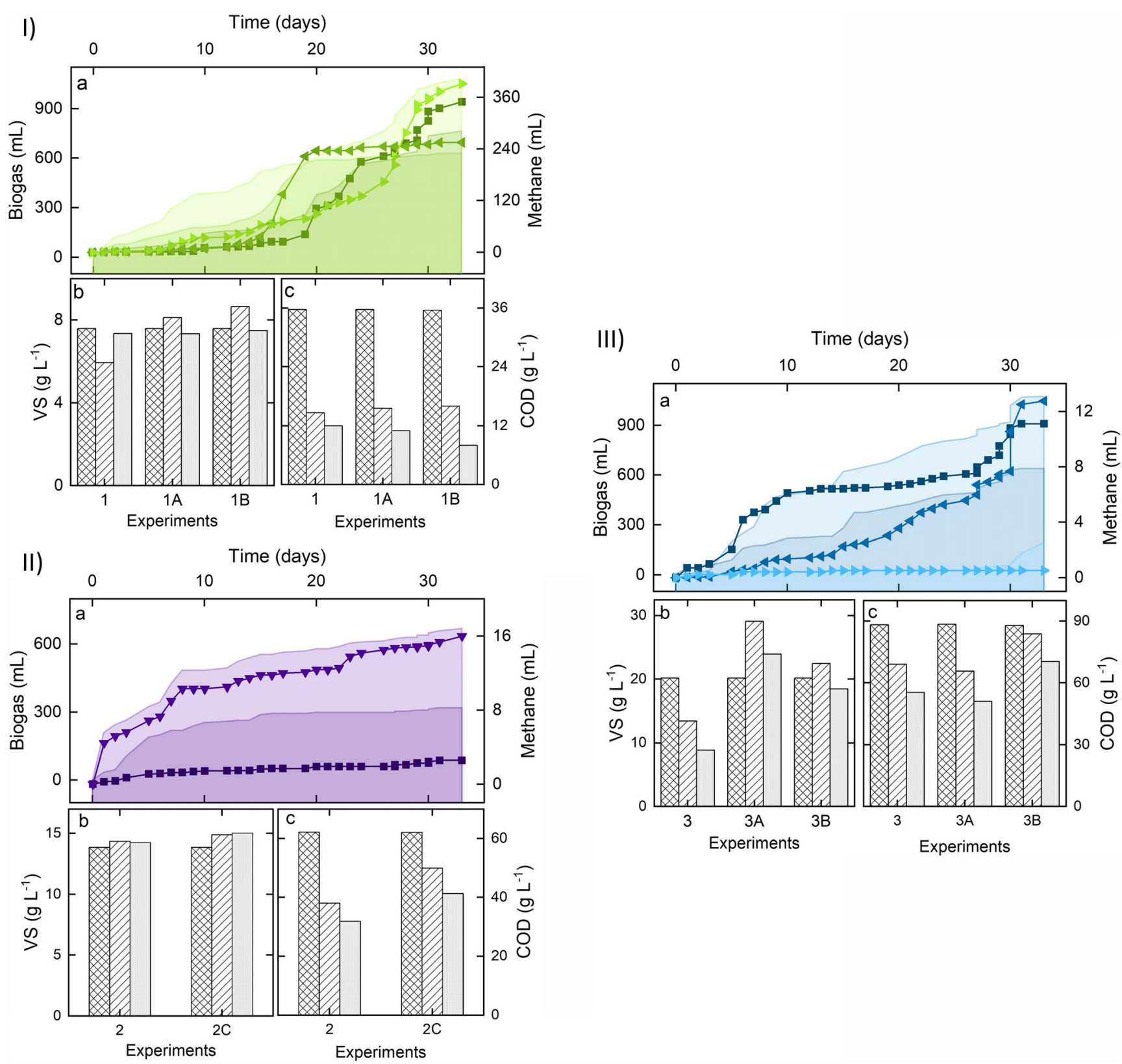

Fig. 3 Results of the PMBR for (I) $0.2 \%$ of CG, (II) $1.7 \%$ of CG, and (III) $3.2 \%$ of CG with control and ultrasound treatment. Methane (area graph) and biogas (line + symbol graph) production in the PMBR in the absence

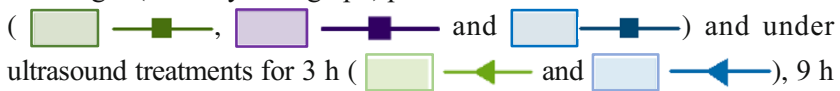

increased the production of biogas and methane by $52 \%$ and $84 \%$, respectively, when compared with that of the control. Nevertheless, the inhibition of methanogenic microorganisms for this $\mathrm{CG}$ concentration caused a degradation of the biogas quality: $5 \%$ (exp. 2) and $6 \%$ (exp. 2C) of methane. In the $2 \mathrm{C}$ experiment, the greatest production of carboxylic acids occurred $\left(2.41 \mathrm{~g} \mathrm{~L}^{-1}\right): 0.18 \mathrm{~g} \mathrm{~L}^{-1}$ of oxalic acid, $1.39 \mathrm{~g} \mathrm{~L}^{-1}$ of acetic acid, and $0.84 \mathrm{~g} \mathrm{~L}^{-1}$ of propionic acid (Fig. 4).

or the assays with the highest $(3.2 \%, \mathrm{v} / \mathrm{v}) \mathrm{CG}$ concentration (Fig. 3III), the initial COD varied between 87.8 and $88.5 \mathrm{~g} \mathrm{~L}^{-1}$,
( $\longrightarrow \longrightarrow$ ), and $15 \mathrm{~h}(\square \longrightarrow$ and $\longrightarrow$ ). The VS (b) and COD (c) for initial (ख), after 15 days (पZZ), and after 30 days (국) of anaerobic digestion

$65 \%$ corresponding to the addition of CG. The volume of biogas generated was $640 \mathrm{~mL}, 1075 \mathrm{~mL}$, and $195 \mathrm{~mL}$ for treatments 3, 3A, and 3B, respectively. The application of ultrasound to the $3.2 \%$ of $\mathrm{CG}(\mathrm{v} / \mathrm{v})$ originated an inverse effect compared with $0.2 \%$ of $C G(\mathrm{v} / \mathrm{v})$. In this case, the biogas production in relation to control decreased by $70 \%$ and increased by $40 \%$ for $15 \mathrm{~h}$ and $3 \mathrm{~h}$ of ultrasound application, respectively. The use of ultrasound causes an increase in the exposure of the microorganisms to the organic load (Tiehm et al. 2001). Therefore, when using a high organic load for a long time, a 


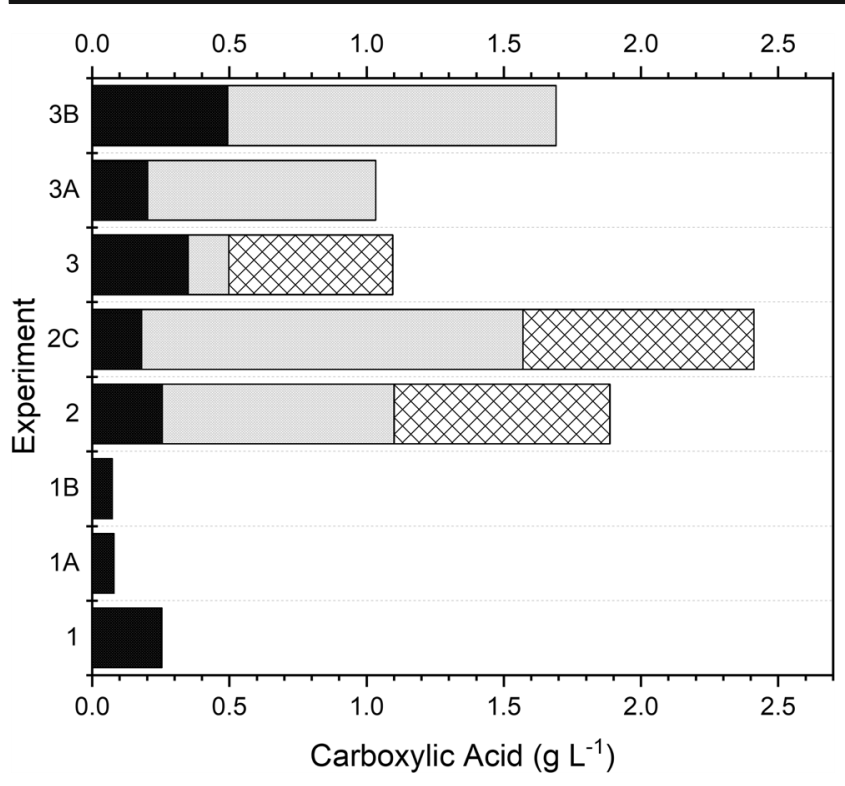

Fig. 4 Carboxylic acid with control and ultrasound treatment in PMBR: propionic acid acetic acid , and oxalic acid

negative effect occurs, evidenced by the high production of oxalic $\left(0.49 \mathrm{~g} \mathrm{~L}^{-1}\right)$ and acetic $\left(1.19 \mathrm{~g} \mathrm{~L}^{-1}\right)$ acids (Fig. 4).

The production of oxalic acid occurred in all experiments (Fig. 4). The metabolic routes leading to oxalic acid involves the formation of oxaloacetate (Kubicek et al. 1988; Munir et al. 2001) according to:

$$
\begin{aligned}
& \mathrm{HOOC}-\mathrm{CH}_{2}-\mathrm{C}(\mathrm{O})-\mathrm{COOH} \rightarrow{ }^{\mathrm{H}_{2} \mathrm{O}} \mathrm{CH}_{3}-\mathrm{COOH} \\
& + \text { HOOC }-\mathrm{COOH}
\end{aligned}
$$

This route produces acetic and oxalic acid at 1:1 molar ratio (1.3:1 mass ratio), both precursors of biogas components:

$$
\begin{aligned}
& \mathrm{CH}_{3}-\mathrm{COOH} \rightarrow \mathrm{CH}_{4}+\mathrm{CO}_{2} \\
& \mathrm{HOOC}-\mathrm{COOH} \rightarrow \mathrm{H}_{2}+2 \mathrm{CO}_{2}
\end{aligned}
$$

The absence of acetic acid in the digestates with the lower $\mathrm{CG}$ concentration is consistent with its consumption through Eq. 2 by the methanogens to produce the amount of methane observed in assays 1, 1A, and $1 \mathrm{~B}$ (roughly $400 \mathrm{~mL} \mathrm{CH}_{4}$ per gram acetic acid). The higher oxalic acid leftovers in assay 1 compared with those in assays $1 \mathrm{~A}$ and $1 \mathrm{~B}$ also relate well with the lower biogas production (roughly $1500 \mathrm{~mL} \mathrm{CO} / \mathrm{H}_{2}$ per gram oxalic acid through Eq. 3). This line of reasoning can be followed to relate the low methane yields of assays with higher CG concentrations due to the presence of acetic acid in the digestate, which confirms the low activity of the methanogens under these conditions. Indeed, the lowest methane yields (2C and $3 \mathrm{~B}$ ) correspond to the larger amounts of non-metabolized acetic acid (1.4 and $1.2 \mathrm{~g} \mathrm{~L}^{-1}$, respectively).

In addition, the use of ultrasound in $1.7 \%$ and $3.2 \%$ glycerol concentrations $(\mathrm{v} / \mathrm{v})$ resulted in higher acetic acid production than that in the controls. Thus, acidogenic and acetogenic microorganisms were favored to produce acetic acid. However, an inhibition of the methanogenic acetoclastic process was evidenced by the low methane production in these conditions.

Propionic acid was detected in digestate of the experiments with $1.7 \%$ CG and with $3.2 \%$ CG concentrations (v/v) in the absence of ultrasound. In all cases, the amounts of propionic acid in the digestate were close to $0.8 \mathrm{~g} \mathrm{~L}^{-1}$. No obvious relationship between ultrasound treatment time and the propionic acid production can be inferred from the data in Fig. 4. The degradation of the glycerol is known to generate propionic acid by the action of the Propionibacterium genera microorganisms as a primary fermentation product and many other microorganisms excrete propionic acid as metabolic by-product (Clomburg and Gonzalez 2013; Da Silva et al. 2009; Gonzalez-Garcia et al. 2017). Propionic acid is a valuable precursor for the chemical industry, and its co-production would be welcome if it were not associated with the low methane production as observed in assays 2, 2C, and 3. According to Weiland (2008), a propionic acid:acetic acid ratio $>1$ along with propionic acid concentration above $1 \mathrm{~g} \mathrm{~L}^{-1}$ are a sign of a malfunction of the anaerobic digestion. These conditions, however, were never met in those assays in which propionic acid was detected. In particular, the lack of microbial activity observed in experiment $3 \mathrm{~B}$ is certainly not related with propionic acid production as this species was not detected in the digestate.

As a general appreciation, the effect of ultrasound treatment time on the methane yield depends on the CG concentration. For the highest CG concentration $(3.2 \%, \mathrm{v} / \mathrm{v})$, the longer exposure to ultrasound caused a severe inhibition of the microbial activity, compared with the control experiment. On the other hand, for the lowest CG concentration in the substrate $(0.2 \%, \mathrm{v} / \mathrm{v})$, the 15 -h ultrasound treatment provided an increase of $11 \%$ in the overall volume of methane produced with respect to the control experiment and a biogas quality peaking at $77 \%$ in methane content. For the treatments with $1.7 \%$ of $\mathrm{CG}(\mathrm{v} / \mathrm{v})$ (Fig. 3II), the use of $9 \mathrm{~h}$ of ultrasound resulted in an improvement of the methane yield compared with the control, yet not enough to compensate for the strong inhibition of the methanogenic microorganisms at this concentration.

\section{Biological treatment}

Figure 5I presents the cumulative methane and biogas production as a function of time for the $\mathrm{CG}$ anaerobic digestion with $\mathrm{A}$. niger or $E$. coli pre-treatment for different $C G$ concentrations in the feed. The data obtained without aerobic biological pretreatment are also presented for reference purposes. The pretreatment substantially modifies the initial substrate VS and COD as shown in Fig. 5 II and III, respectively. The starting COD would amount to $25 \mathrm{~g} \mathrm{~L}^{-1}$ (3.6 $\mathrm{g} \mathrm{L}^{-1}$ from CG), $52 \mathrm{~g} \mathrm{~L}^{-1}$ 

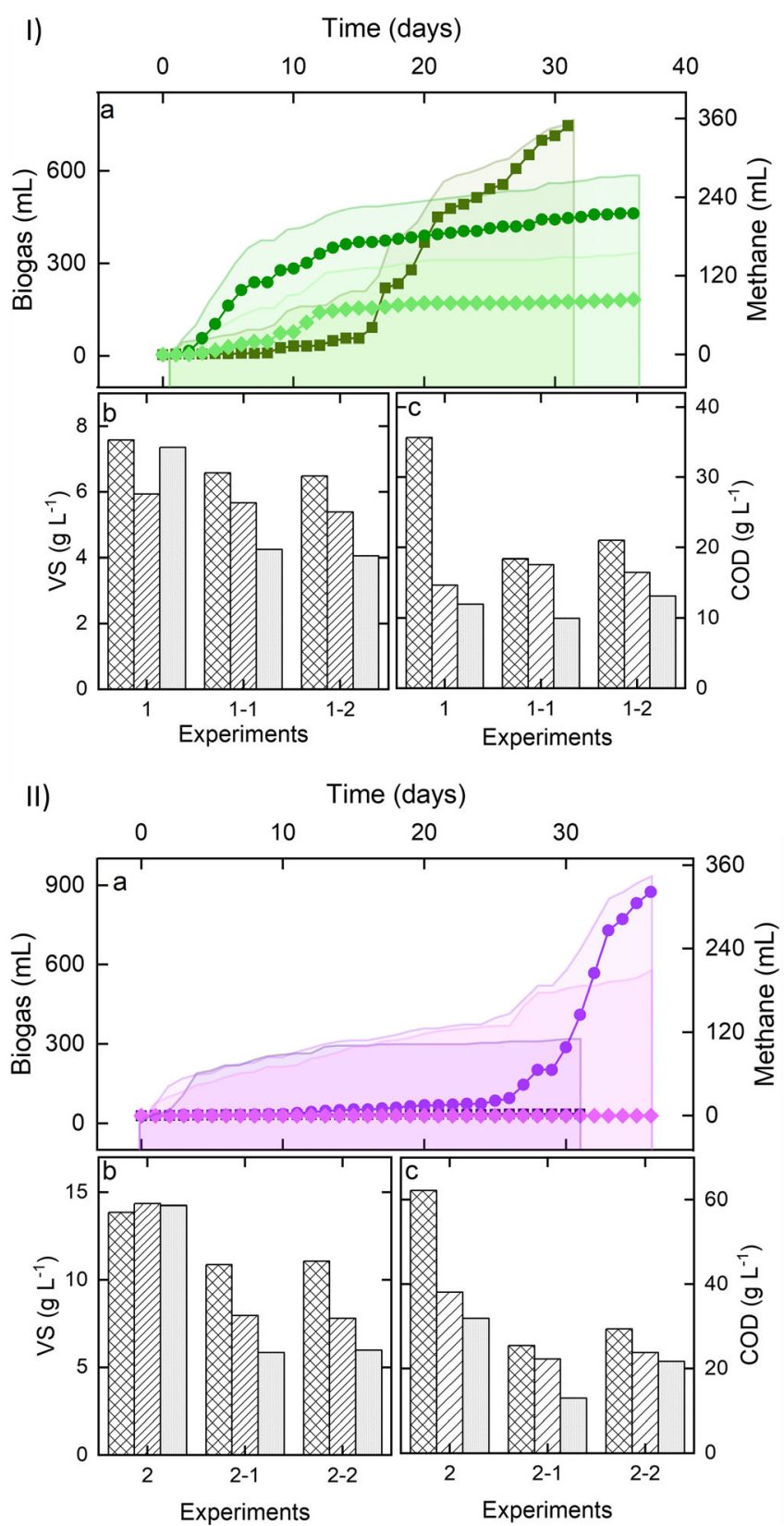

Fig. 5 Results of the PMBR for (I) $0.2 \%$ of CG, (II) $1.7 \%$ of CG, and (III) $3.2 \%$ of CG with control and biological treatment. Methane (area graph) and biogas (line + symbol graph) production in the PMBR in the absence $(\square-\square-\square-$, and $\square-\square-$ and under biological treatments with A. niger $(\square-\infty-, \square-$, and

(30.7 $\mathrm{g} \mathrm{L}^{-1}$ from CG), and $79 \mathrm{~g} \mathrm{~L}^{-1}\left(57.9 \mathrm{~g} \mathrm{~L}^{-1}\right.$ from $\mathrm{CG}$ ) for the CG concentrations of $0.2,1.7$, and $3.2 \%(\mathrm{v} / \mathrm{v})$, respectively. The difference between these values and those in Fig. $5 \mathrm{III}$ is due to the CG COD degradation during the pre-treatment, assuming the COD from the microorganisms to be negligible. The mean initial consumption of COD was $16 \pm 2 \mathrm{~g} \mathrm{~L}^{-1}, 35 \pm 3 \mathrm{~g} \mathrm{~L}^{-1}$, and $45 \pm 2 \mathrm{~g}$ $\mathrm{L}^{-1}$ for $0.2,1.7$, and $3.2 \% \mathrm{CG}$ content, respectively. The COD removal in the anaerobic digestion was higher for $A$. niger than for $E$. coli pre-treatments.

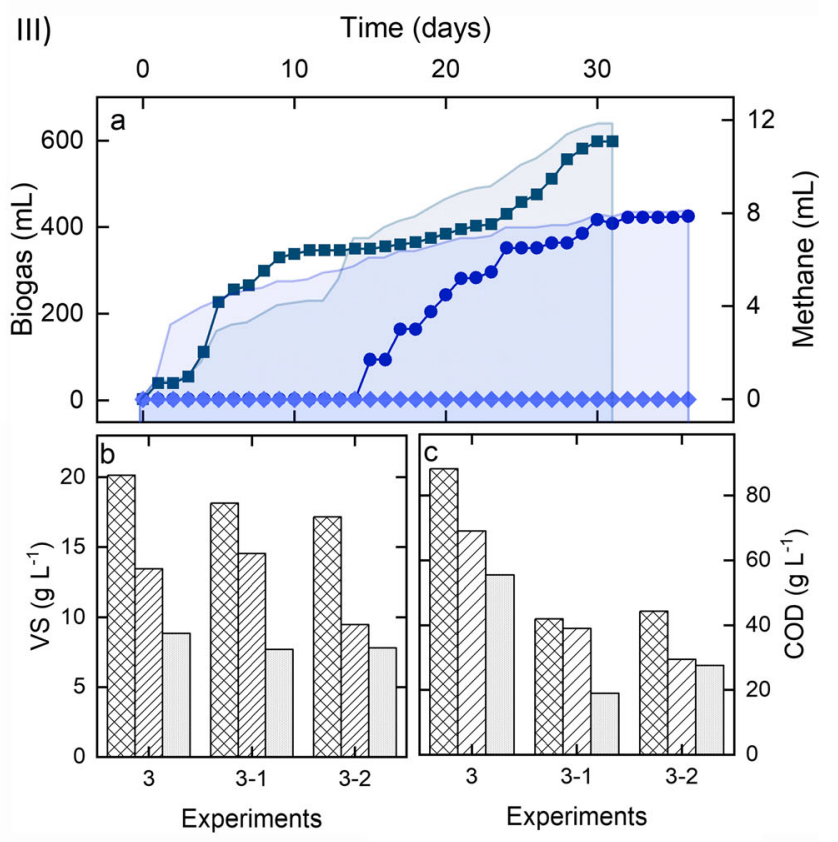

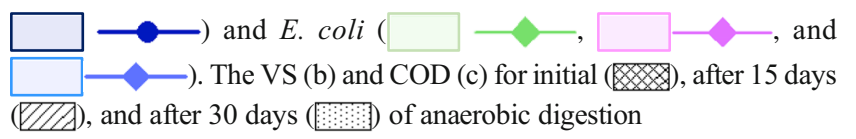

The VS also varies during the pre-treatment, but not pari passu with the COD decrease, thus indicating that the A. niger and $E$. coli have metabolized the CG to highly oxidized compounds ( $\mathrm{C} 2$ or $\mathrm{C} 3$ carboxylic acids most likely) during the pretreatment. For $0.2 \%$ CG initial concentration (v/v), most of the CG COD is depleted in the pre-treatment. However, its low COD derivatives apparently provide a rich substrate for the methanogens. Considering the initial COD as $25 \mathrm{~g} \mathrm{~L}^{-1}$, the pre-treatment with $A$. niger resulted in a methane yield of 
$47.7 \mathrm{~mL} \mathrm{CH}_{4} \mathrm{~g}^{-1} \mathrm{COD}$, nearly equal to the control experiment (49.2 $\mathrm{mL} \mathrm{CH}_{4} \mathrm{~g}^{-1} \mathrm{COD}$ ). The pre-treatment with E. coli, on the other hand, resulted in a lower methane yield $(23.5 \mathrm{~mL}$ $\mathrm{CH}_{4} \mathrm{~g}^{-1} \mathrm{COD}$ ).

The biodegradation by $E$. coli led to a reduction in methane production in all the experiments for the three CG concentrations (Table 2; experiments 1-2, 2-2, and 3-2). Moreover, a total inhibition of methanogenic microorganisms was observed for $1.7 \%$ and $3.2 \%$ CG concentrations (v/v).

The biodegradation by $A$. niger had a negative impact on the anaerobic digestion of 0.2 and $3.2 \%$ CG concentrations (v/v). Using $0.2 \%$ CG (v/v) (Table 2; experiment 1-1) a $38 \%$ reduction in methane production in relation to the control was observed, which may be related to the consumption of the COD $(48 \%)$ in the aerobic biological treatment. For 3.2\% CG $(\mathrm{v} / \mathrm{v})$, despite the initial COD decrease by $52 \%$, there was inhibition of methanogenic microorganisms and an accumulation of acetic acid. However, biodegradation by A. niger enhanced the anaerobic digestion for the assay with $1.7 \%$ CG $(\mathrm{v} / \mathrm{v})$ (Table 2; experiment 2-1), leading to a $99 \%$ increase in methane production in relation to the control.

For the concentration of $0.2 \% \mathrm{CG}(\mathrm{v} / \mathrm{v})$, the biodegradation led to similar COD reductions: $17 \mathrm{~g} \mathrm{~L}^{-1}$ for A. niger and $15 \mathrm{~g}$ $\mathrm{L}^{-1}$ for $E$. coli. However, the biogas yield was higher for A. niger ( $585 \mathrm{~mL}$ of biogas with $58 \%$ methane) than for E. coli ( $335 \mathrm{~mL}$ of biogas with $44 \%$ of methane). For this CG concentration, there was only the production of oxalic acid (Fig. 6) and no inhibition was evidenced by the presence of propionic and acetic acids. However, both biological treatments resulted in a lower biogas yield than the control (765 $\mathrm{mL}$ of biogas with $75 \%$ methane), which is explained by the initial COD loss.

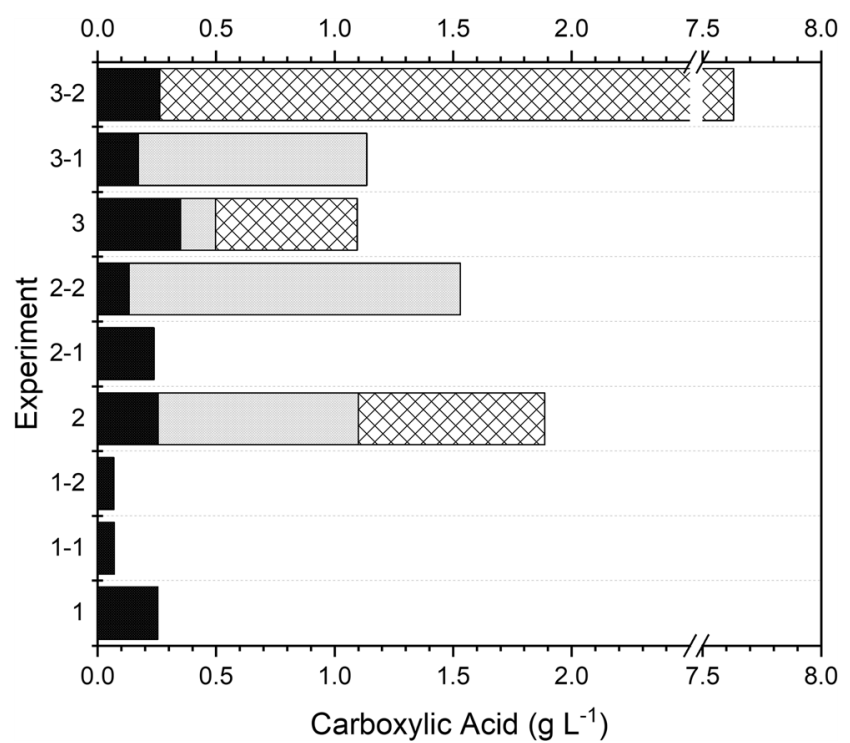

Fig. 6 Carboxylic acid with control and microorganisms in PMBR: propionic acid acetic acid and oxalic acid
For the concentration of $1.7 \% \mathrm{CG}(\mathrm{v} / \mathrm{v})$, the previous biodegradation of glycerol increased the biogas production in relation to the control, $66 \%$ for A. niger and $45 \%$ for E. coli. The A. niger pre-treatment of the feed with $1.7 \%$ CG concentration $(\mathrm{v} / \mathrm{v})$ provided an excellent methane yield during the anaerobic digestion of the treated substrate, with $86 \mathrm{~mL} \mathrm{CH}_{4}$ $\mathrm{g}^{-1}$ COD for the anaerobic digestion phase only and $27 \mathrm{~mL}$ $\mathrm{CH}_{4} \mathrm{~g}^{-1} \mathrm{COD}$ overall (including the COD depleted during the pre-treatment). The overall methane yield is much greater than the $0.3 \mathrm{~mL} \mathrm{CH}_{4} \mathrm{~g}^{-1} \mathrm{COD}$ yield observed for the control experiment. About $86 \%$ of the initial CG COD was removed during the pre-treatment, indicating the high activity of A. niger for glycerol digestion. Indeed, A. niger has been used for the bioproduction of organic acids, mainly oxalic acid, from glycerol with high conversion efficiency at similar CG concentration (André et al. 2010). The digestate contained only oxalic acid residuals in small quantities (Fig. 6), indicating that gas-producing microorganisms, mainly the methanogens, regained their activity by the end of the anaerobic digestion (Fig. 5I), despite the inhibition at the initial stages.

In the experiments carried out with $3.2 \% \mathrm{CG}(\mathrm{v} / \mathrm{v})$, there was a reduction of the initial COD by around $50 \%$, but this was not enough to improve the methane production. According to some researchers, the accumulation of propionic acid in the digested material may be related to an inhibiting effect on the anaerobic digestion process (Pullammanappallil et al. 2001). The high CG load can be the cause of the accumulation of carboxylic acids in the digested material (Fig. 6). On the other hand, the propionic acid produced from glycerol fermentation has a wide range of applications in organic synthesis, food, perfume, paint, and pharmaceutical industries (Martínez-Campos and de la Torre 2002). As the efficiency of propionic acid extraction by distillation is strongly limited by the presence of acetic acid, the low concentration of this acid can greatly increase the yield of the propionic acid recovered by distillation (Liu et al. 2012). In experiment 3-2 (Table 2), there was a formation of propionic acid without the generation of acetic acid (Fig. 6).

Oxalic acid was produced in all experiments (Figs. 4 and 6), being its generation characteristic of the source of carbon to the microorganisms. André et al. (2010) used waste biodiesel-derived glycerol as a carbon source for fungus under nitrogen limitation conditions, resulting in the accumulation of intracellular lipids that led to the secretion of oxalic acid by the microorganisms.

As a concluding remark for this section, the results suggest during the pre-treatment with A. niger, most of the CG is metabolized to oxalic and acetic acids which can be further bioprocessed by the microorganisms in the sludge to produce methane with increased efficiency. The A. niger acts as an efficient substitute for the acidogenic and acetogenic 
microorganisms in the $\mathrm{CG}$ digestion in a way that greatly increases the tolerance to higher CG concentrations in the feed.

\section{Upflow anaerobic sludge blanket reactor}

Internal temperature control is important for the stability of the anaerobic digestion process. The anaerobic microorganisms originate higher methane yields at mesophilic (30-40 ${ }^{\circ} \mathrm{C}$ ) and thermophilic $\left(45-60^{\circ} \mathrm{C}\right)$ temperature ranges. In addition, methanogenic microorganisms do not withstand drastic temperature changes (Kumaran et al. 2016). In this study, the temperature inside the reactor varied between 40 and $43.8{ }^{\circ} \mathrm{C}$ (average temperature of $\approx 42{ }^{\circ} \mathrm{C}$; Table 3).

The recommended $\mathrm{pH}$ value for anaerobic digestion must be between 6 and 8 . This parameter is directly related to alkalinity, which gives a buffer effect to the system (Yadvika et al. 2004). The UASB reactor operated at a $\mathrm{pH}$ range of 6.4-6.8. The $\mathrm{pH}$ variations occurred when there was a change in $\mathrm{CG}$ concentration (weeks 6-8). For an organic load of $0.4 \mathrm{~kg} \mathrm{COD}$ $\mathrm{m}^{-3}$ reactor day ${ }^{-1}$, the average $\mathrm{pH}$ was $6.7 \pm 0.2$ and $6.4 \pm 0.2$ in weeks $1-3$ and 4-5, respectively, and when the organic load increased to $2.9 \mathrm{~kg} \mathrm{COD} \mathrm{m}^{-3}$ reactor day ${ }^{-1}$, the $\mathrm{pH}$ remained at $6.8 \pm 0.4$ and $6.60 \pm 0.09$ in weeks $6-8$ and 9-10, respectively. The alkalinity added to the reactor was proportional to the concentration of glycerol. Thus, the $\mathrm{pH}$ values show small variations for different volumetric organic loads.
The feed solution, for the organic load of $0.4 \mathrm{~kg} \mathrm{COD} \mathrm{m}^{-3}$ reactor $\mathrm{day}^{-1}$ (corresponding to $0.2 \%$ of glycerol, v/v), presented COD values of $3.39 \pm 0.01 \mathrm{~g} \mathrm{~L}^{-1}$ and $3.38 \pm 0.01 \mathrm{~g}$ $\mathrm{L}^{-1}$, for weeks 1-3 and 4-5, respectively, despite the fact that in weeks 4-5, ultrasound was applied to the feed solution for $15 \mathrm{~h}$. As previously mentioned, ultrasound may improve LCFA hydrolysis. This effect was observed in the increase of VS in the feed solution (Fig. 7c) and lower phosphorus consumption (Fig. 7b) by microorganisms in anaerobic digestion. Phosphorus provides energy in the form of ATP and ADP, which is used by microorganisms to break down molecules (Biebl et al. 1999). In addition, at weeks 4-5, a slight increase in COD removal was observed (Fig. 7a).

The feed solution presented COD values of $20.7 \pm 0.3 \mathrm{~g} \mathrm{~L}^{-1}$ and $10.2 \pm 0.3 \mathrm{~g} \mathrm{~L}^{-1}$ in weeks 6-8 and weeks 9-10, respectively. However, in weeks 9-10, the aerobic treatment using a A. niger culture was employed upstream from the UASB, which resulted in a $51 \%$ reduction in the feed COD concentration (Fig. 7a), as observed in the case of the batch reactor. In this case, phosphorus consumption was also lower due to the lower organic load fed to the UASB reactor (Fig. 7b). In weeks 9-10, it was possible to observe a small increase in the concentration of VS at the UASB inlet, which may be related to the leaching of biomass from the aerobic reactor. In addition, the removal of VS in the digested material was higher (Fig. 7c).

Feeding the UASB reactor at $0.4 \mathrm{~kg} \mathrm{COD} \mathrm{m}^{-3}$ reactor day $^{-1}$, a slight increase in COD removal was observed between

Table 3 Results obtained using the upflow anaerobic sludge blanket reactor

\begin{tabular}{|c|c|c|c|c|c|}
\hline \multirow[t]{2}{*}{ Prameters } & \multirow[t]{2}{*}{ Unit } & \multicolumn{4}{|l|}{ Weeks } \\
\hline & & $1-3$ & $4-5$ & $6-8$ & $9-10$ \\
\hline $\mathrm{pH}$ & & $6.7 \pm 0.2$ & $6.4 \pm 0.2$ & $6.8 \pm 0.4$ & $6.60 \pm 0.09$ \\
\hline Temperature & ${ }^{\circ} \mathrm{C}$ & $42 \pm 1$ & $42.5 \pm 0.7$ & $42 \pm 1.0$ & $42.3 \pm 0.5$ \\
\hline $\mathrm{COD}_{\mathrm{IN}}$ & $\mathrm{g} \mathrm{L}^{-1}$ & $3.39 \pm 0.01$ & $3.38 \pm 0.01$ & $20.7 \pm 0.3$ & $10.2 \pm 0.3$ \\
\hline $\mathrm{COD}_{\text {OUT }}$ & & $1.2 \pm 0.1$ & $1.05 \pm 0.05$ & $15.7 \pm 0.2$ & $2.4 \pm 0.4$ \\
\hline COD & $\%$ removal & $65 \pm 4$ & $69 \pm 2$ & $24 \pm 1$ & $77 \pm 2$ \\
\hline Phosphorus $_{\text {IN }}$ & $m g L^{-1}$ & $65 \pm 7$ & $60 \pm 8$ & $(40 \pm 6) \times 10^{1}$ & $178 \pm 8$ \\
\hline Phosphorus & & $43 \pm 5$ & $51 \pm 4$ & $(23 \pm 5) \times 10^{1}$ & $116 \pm 3$ \\
\hline Phosphorus & $\%$ removal & $34 \pm 1$ & $14 \pm 4$ & $41 \pm 9$ & $35 \pm 1$ \\
\hline $\mathrm{VS}_{\mathrm{IN}}$ & $\mathrm{g} \mathrm{L}^{-1}$ & $0.83 \pm 0.01$ & $0.95 \pm 0.02$ & $5.3 \pm 0.2$ & $5.62 \pm 0.04$ \\
\hline $\mathrm{VS}_{\text {OUT }}$ & & $0.61 \pm 0.01$ & $0.6 \pm 0.1$ & $2.7 \pm 0.1$ & $1.46 \pm 0.03$ \\
\hline VS & $\%$ removal & $26 \pm 1$ & $39 \pm 9$ & $49 \pm 4$ & $74 \pm 1$ \\
\hline $\mathrm{VS} / \mathrm{TS}$ in reactor & - & $0.6 \pm 0.1$ & $0.54 \pm 0.05$ & $0.52 \pm 0.04$ & $0.54 \pm 0.06$ \\
\hline Oxalic acid & $\mathrm{g} \mathrm{L}^{-1}$ & $0.014 \pm 0.005$ & $0.012 \pm 0.001$ & $0.09 \pm 0.02$ & $0.085 \pm 0.006$ \\
\hline Acetic acid & & n.d. & n.d. & n.d. & $0.2 \pm 0.1$ \\
\hline Propionic acid & & $0.23 \pm 0.05$ & $0.05 \pm 0.02$ & n.d & n.d \\
\hline \multirow[t]{2}{*}{ Methane production } & $\mathrm{m}^{3} \mathrm{CH}_{4} \mathrm{~kg}^{-1}$ COD removal & $0.42 \pm 0.08$ & $0.6 \pm 0.1$ & $0.12 \pm 0.06$ & $0.43 \pm 0.07$ \\
\hline & $\mathrm{m}^{3} \mathrm{CH}_{4} \mathrm{~kg}^{-1} \mathrm{VS}$ & $0.41 \pm 0.08$ & $0.6 \pm 0.1$ & $0.13 \pm 0.06$ & $0.6 \pm 0.1$ \\
\hline Quality of biogas & $\% \mathrm{CH}_{4}$ & $71 \pm 7$ & $80 \pm 2$ & $(6 \pm 1) \times 10^{1}$ & $73 \pm 9$ \\
\hline
\end{tabular}



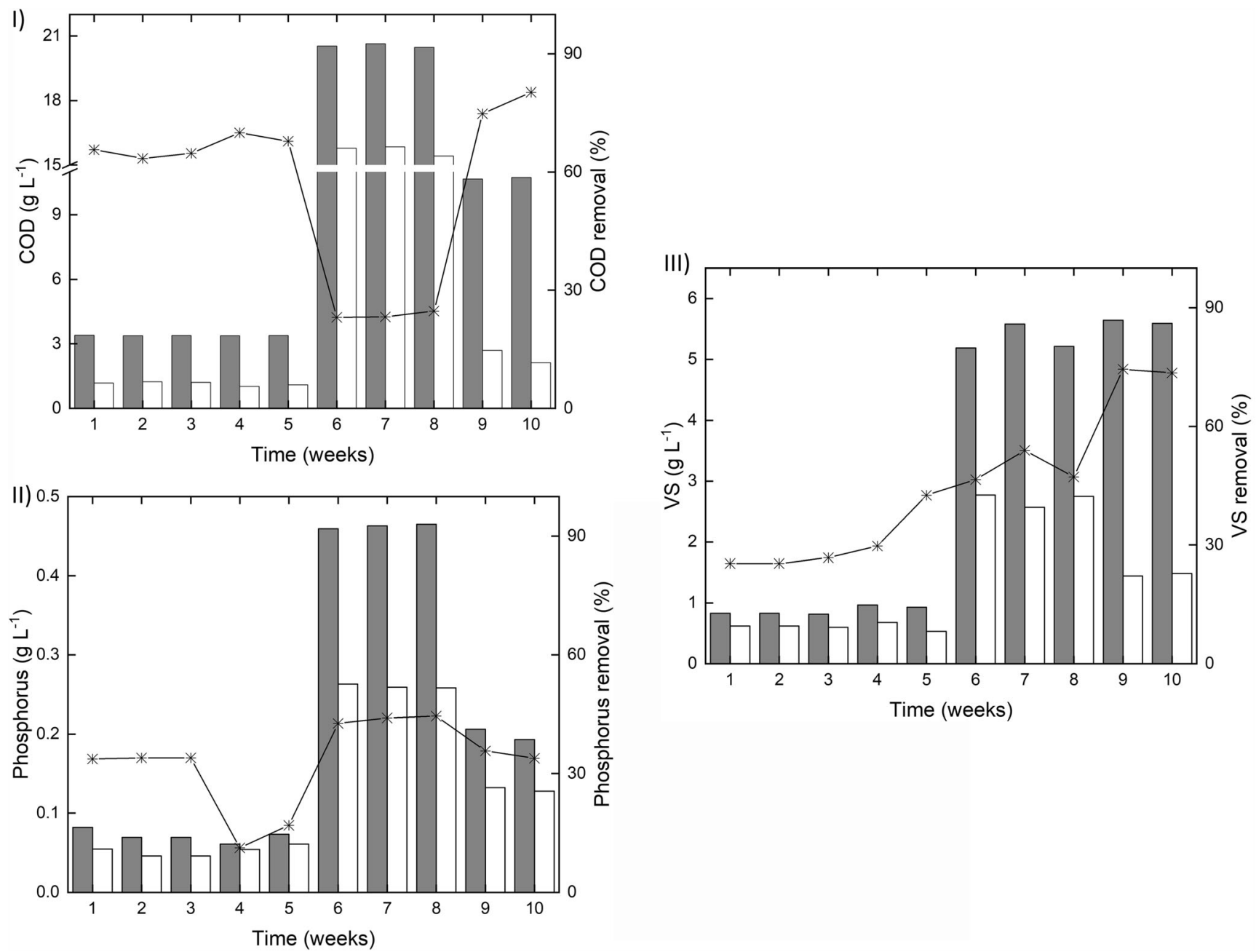

Fig. 7 COD (a), phosphorous (b) and VS (c) concentration in the feed (filled bars) and outlet (empty bars) stream of the UASB reactor and the respective percentage of removal (一米-)

weeks $1-3$ and $4-5$. In this case, the application of ultrasound to the feed solution gradually improved the methane production; i.e., ultrasound application caused a positive impact on methane production. After increasing the organic load to $2.9 \mathrm{~kg} \mathrm{COD} \mathrm{m}^{-3}$ reactor day ${ }^{-1}$ (weeks 6-8), a sudden drop in methane production occurred. However, when the UASB reactor started to be fed by the stream from the $A$. niger aerobic treatment (weeks 9-10), methane production soon began to increase (Fig. 8a).

The theoretical maximum methane yield value for the temperature of $42{ }^{\circ} \mathrm{C}$ is $0.4 \mathrm{~L} \mathrm{CH}_{4} \mathrm{~g}^{-1} \mathrm{COD}_{\text {removal. }}$. However, a higher methane yield can be probably related to the biodegradable COD accumulated in the decanter and returning to the reactor. Furthermore, the biomass in the reactor may gradually adapt to previously non-degradable material and convert this material into methane.

In the UASB reactor, the feed treatment with ultrasound resulted in $0.547 \mathrm{~m}^{3} \mathrm{CH}_{4} \mathrm{~kg}^{-1} \mathrm{COD}$ removal and $0.573 \mathrm{~m}^{3}$ $\mathrm{CH}_{4} \mathrm{~kg}^{-1} \mathrm{VS}$ production (weeks 4-5), which means a methane production increase of $29 \%$ when applying ultrasound compared with an increase of only $11 \%$ achieved in the batch reactor. The energy gain of $0.05 \mathrm{kWh}$ day $^{-1}$ resulting from the use of ultrasound does not meet the energy expenditure, which is explained by the ultrasound method used (ultrasound bath). The ultrasound dissipates in the liquid after passing a glass bottle interface which acts as a barrier to ultrasonic waves. Thus, a longer time for the ultrasound treatment was required. Therefore, it would be necessary to optimize the ultrasonic equipment for a better energy balance, then allowing for a shorter operating time.

Methane production is directly associated with the presence of carboxylic acids in the digested material (Fig. 8b). Between weeks 1 and 5, propionic and oxalic acid were produced. Propionic acid is a short-chain fatty acid of difficult degradation and its accumulation in the digested material indicates that there was inhibition of the acetogenic and methanogenic microorganisms. In this case, the application of the ultrasound increased the biogas production and led to a lower accumulation of propionic acid in the digested material. This 

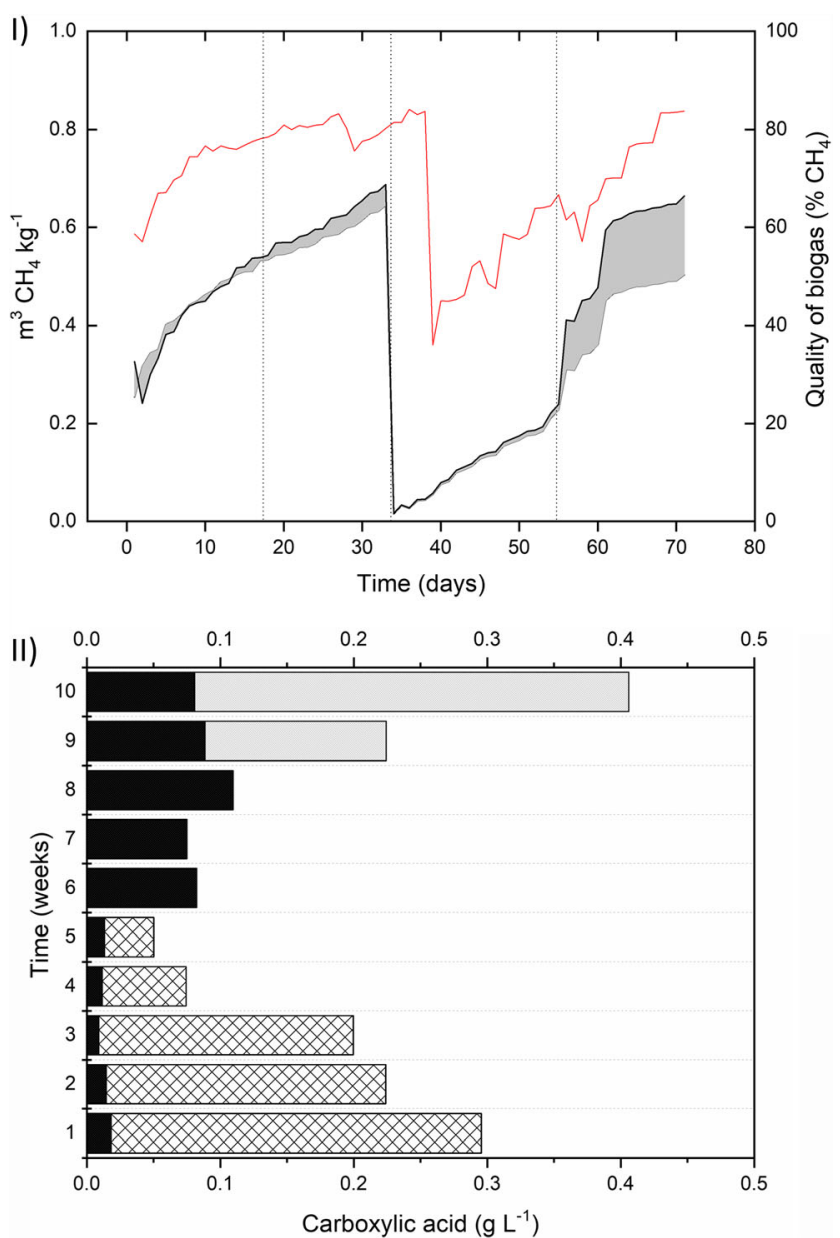

Fig. 8 Methane production (a) and carboxylic acid in UASB reactor (b). $\mathrm{m}^{3} \mathrm{CH}_{4} \mathrm{~kg}^{-1} \mathrm{COD}$ removal - in $\mathrm{m}^{3} \mathrm{CH}_{4} \mathrm{~kg}^{-1} \mathrm{VS}$-, quality of biogas (\% methane) - , propionic acid , acetic acid and oxalic acid \%

may be due to the promotion of LCFA hydrolysis by the ultrasound treatment.

After CG degradation in feedstock by A. niger, the methane yield was $0.434 \mathrm{~m}^{3} \mathrm{CH}_{4} \mathrm{~kg}^{-1} \mathrm{COD}$ removal or $0.573 \mathrm{~m}^{3} \mathrm{CH}_{4}$ $\mathrm{kg}^{-1} \mathrm{VS}$ (weeks 4-5). The treatment with A. niger increased the methane production by $77 \%$ compared with the digestion applied to the same feedstock load but without previous biological treatment. Similar results of methane production $\left(0.590 \mathrm{~m}^{3} \mathrm{CH}_{4} \mathrm{~kg}^{-1} \mathrm{VS}\right)$ were found by Castrillón et al. (2013) working on glycerol co-digestion (cattle manure + $6 \%$ of $\mathrm{CG}$ ). Energy production considering methane production could be $0.09 \mathrm{kWh}^{-1} \mathrm{yy}^{-1}$ at weeks $6-8$ and $0.54 \mathrm{kWh}$ $\mathrm{day}^{-1}$ at weeks 9-10. The energy cost for the aeration of the biological reactor was $0.06 \mathrm{kWh}$ day $^{-1}$; thus, the biological treatment generated an energy gain of $0.48 \mathrm{kWh} \mathrm{day}^{-1}$ compared with the control.

Between weeks 6 and 10, it was possible to detect the production of oxalic and acetic acid. The acetic acid only appeared at weeks 9-10 (after A. niger biological treatment).
The reduction of acetic acid by acetoclastic methanogenic microorganisms accounts for $70 \%$ of total methane production (Valcke and Verstraete 1983). Thus, the aerobic treatment using a pure culture of $A$. niger favored the production of acetic acid and consequently the production of methane (Fig. 8a, b). Oppositely, in weeks 6-8 (absence of A. niger biological treatment), the lack of propionic and oxalic acids together with a low methane production may indicate anaerobic digestion inhibition by the high organic load.

In the continuous UASB reactor, the production of oxalic acid increased according to the increase of CG loading in the feed. There is a route of cytoplasmic degradation of glycerol to oxalic acid as described in the literature (Kubicek et al. 1988). This route does not pass through the mitochondria and does not depend on the oxidation, being able to explain this result.

\section{Conclusions}

The effect of the treatment used on the overall efficiency of the anaerobic digestion process depends on the crude glycerol (CG) concentration. In the batch test with the lower CG concentration $(0.2 \% \mathrm{CG}, \mathrm{v} / \mathrm{v})$, the ultrasound treatment applied to the mixture of sludge and substrate enhanced the methane production by $11 \%$. However, when employing the aerobic biological treatment, part of the degraded material is consumed, which leads to a decrease in methane production. On the other hand, ultrasound treatment can improve $\mathrm{AD}$ when there is no inhibition of methanogenic microorganisms (control with $0.2 \% \mathrm{CG}, \mathrm{v} / \mathrm{v})$. Higher CG concentrations ( $1.7 \%$ and $3.2 \% \mathrm{CG}$ concentrations, $\mathrm{v} / \mathrm{v}$ ) inhibit methanogenic microorganisms and the ultrasound treatment was unable to avoid this inhibition, leading to low methane production. In this case, aerobic biological treatment with $A$. niger may be the solution. The A. niger treatment with $1.7 \% \mathrm{CG}(\mathrm{v} / \mathrm{v})$ and anaerobic digestion in a batch reactor increased the methane production by $99 \%$ in relation to control. Nevertheless, when CG concentration was high $(3.2 \% \mathrm{CG}, \mathrm{v} / \mathrm{v})$, even with the decrease of the organic load after aerobic biological treatment, there is inhibition of the methanogenic microorganisms by the excess of carboxylic acids produced, leading to a reduction of the methane production in all assays.

Continuous experiments were carried out in a UASB reactor using feed streams with $0.2 \% \mathrm{CG}$ and $1.7 \% \mathrm{CG}$ concentrations $(\mathrm{v} / \mathrm{v})$, which corresponds to organic loads of $0.4 \mathrm{~kg}$ $\mathrm{COD} \mathrm{m}^{-3}$ day $^{-1}$ and $2.9 \mathrm{~kg} \mathrm{COD} \mathrm{m}^{-3}$ day $^{-1}$, respectively. The application of ultrasound to the $0.4 \mathrm{~kg} \mathrm{COD} \mathrm{m}^{-3}$ day $^{-1}$ feed load resulted in an increase of $29 \%$ in the methane production $\left(0.547 \mathrm{~m}^{3} \mathrm{CH}_{4} \mathrm{~kg}^{-1} \mathrm{COD}_{\text {removal }}\right.$ or $0.573 \mathrm{~m}^{3} \mathrm{CH}_{4} \mathrm{~kg}^{-1} \mathrm{VS}$; methane content in the biogas $=80 \%$ ) in relation to control. Moreover, treating $2.9 \mathrm{~kg} \mathrm{COD} \mathrm{m}^{-3}$ day $^{-1}$ by A. niger, upstream the anaerobic reactor, the methane production 
increased by $77 \%\left(0.434 \mathrm{~m}^{3} \mathrm{CH}_{4} \mathrm{~kg}^{-1} \mathrm{COD}_{\text {removal }}\right.$ or $0.573 \mathrm{~m}^{3}$ $\mathrm{CH}_{4} \mathrm{~kg}^{-1} \mathrm{VS}$; methane content in the biogas $=73 \%$ ).

Besides the energetic valorization of glycerol by the production of methane, carboxylic acids (propionic acid, acetic acid and oxalic acid) were identified in the digested material. The oxalic acid was always produced. The aerobic biological treatment by $A$. niger led to the production of acetic acid by anaerobic digestion, thus favoring the methanogenic acetoclastic microorganisms. The methane production increased and an energy gain of $0.48 \mathrm{kWh} \mathrm{day}^{-1}$ compared with the control was obtained. Furthermore, the ultrasound treatment decreased the production of carboxylic acids for an organic load of $0.2 \% \mathrm{CG}(\mathrm{v} / \mathrm{v})$ and increased the biogas production. However, for $1.7 \% \mathrm{CG}$ and $3.2 \% \mathrm{CG}$ concentrations $(\mathrm{v} / \mathrm{v})$, there was an increase in the production of the carboxylic acids.

According to the obtained results, further studies can be done using ultrasound as $\mathrm{AD}$ treatment for other types of substrates with low solubility. For future work, it would be interesting to use more efficient ultrasonic probes, which could reduce energy expenditure. In addition, the use of AD-coupled A. niger treatment can be tested on oily substrates containing LCFA. Thus, these physical or aerobic biological treatments may potentially improve methane production from the anaerobic digestion of other substrate types.

Funding information This work was financially supported by: Associate Laboratory LSRE-LCM - UID/EQU/50020/2019 - funded by national funds through FCT/MCTES (PIDDAC). L.O. Paulista acknowledges FCT for his scholarship (SFRH/BD/137639/2018). V.J.P. Vilar acknowledges the FCT Individual Call to Scientific Employment Stimulus 2017 (CEECIND/01317/2017).

\section{References}

Afabor E, Salama A, Ibrahim H (2017) Packed bed reactor modeling of the catalytic auto-thermal reforming of synthetic crude glycerol. J Environ Chem Eng 5:4850-4857. https://doi.org/10.1016/j.jece. 2017.09.016

Al-Jamal W, Mahmoud N (2009) Community onsite treatment of cold strong sewage in a UASB-septic tank. Bioresour Technol 100:10611068. https://doi.org/10.1016/j.biortech.2008.07.050

Almena A, Martín M (2015) Technoeconomic analysis of the production of epichlorohydrin from glycerol. Ind Eng Chem Res 55:32263238. https://doi.org/10.1021/acs.iecr.5b02555

André A, Diamantopoulou P, Philippoussis A, Sarris D, Komaitis M, Papanikolaou S (2010) Biotechnological conversions of bio-diesel derived waste glycerol into added-value compounds by higher fungi: production of biomass, single cell oil and oxalic acid. Ind Crop Prod 31:407-416. https://doi.org/10.1016/j.indcrop.2009.12.011

Apha A (1998) Wef. Standard methods for the examination of water and wastewater

Biebl H, Menzel K, Zeng A-P, Deckwer W-D (1999) Microbial production of 1, 3-propanediol. Appl Microbiol Biotechnol 52:289-297. https://doi.org/10.1007/s002530051523
Buchauer K (1998) A comparison of two simple titration procedures to determine volatile fatty acids in influents to waste-water and sludge treatment processes. Water SA-Pretoria 24:49-56

Castrillón L, Fernández-Nava Y, Ormaechea P, Marañón E (2013) Methane production from cattle manure supplemented with crude glycerin from the biodiesel industry in CSTR and IBR. Bioresour Technol 127:312-317. https://doi.org/10.1016/j.biortech.2012.09. 080

Chatzifragkou A, Papanikolaou S (2012) Effect of impurities in biodieselderived waste glycerol on the performance and feasibility of biotechnological processes. Appl Microbiol Biotechnol 95:13-27. https://doi.org/10.1007/s00253-012-4111-3

Clomburg JM, Gonzalez R (2013) Anaerobic fermentation of glycerol: a platform for renewable fuels and chemicals. Trends Biotechnol 31: 20-28. https://doi.org/10.1016/j.tibtech.2012.10.006

Da Silva GP, Mack M, Contiero J (2009) Glycerol: a promising and abundant carbon source for industrial microbiology. Biotechnol Adv 27:30-39. https://doi.org/10.1016/j.biotechadv.2008.07.006

Dobrowolski A, Mituła P, Rymowicz W, Mirończuk AM (2016) Efficient conversion of crude glycerol from various industrial wastes into single cell oil by yeast Yarrowia lipolytica. Bioresour Technol 207: 237-243. https://doi.org/10.1016/j.biortech.2016.02.039

Gonzalez-Garcia R, McCubbin T, Navone L, Stowers C, Nielsen L, Marcellin E (2017) Microbial propionic acid production. Fermentation 3:21. https://doi.org/10.3390/fermentation3020021

He S, Muizebelt I, Heeres A, Schenk NJ, Blees R, Heeres HJ (2018) Catalytic pyrolysis of crude glycerol over shaped ZSM-5/bentonite catalysts for bio-BTX synthesis. Appl Catal B Environ 235:45-55. https://doi.org/10.1016/j.apcatb.2018.04.047

Hu S, Luo X, Wan C, Li Y (2012) Characterization of crude glycerol from biodiesel plants. J Agric Food Chem 60:5915-5921. https://doi.org/ 10.1021/jf3008629

Hutňan M, Kolesárová N, Bodík I (2013) Anaerobic digestion of crude glycerol as sole substrate in mixed reactor. Environ Technol 34: 2179-2187. https://doi.org/10.1080/09593330.2013.804581

Iyyappan J, Baskar G, Bharathiraja B, Saravanathamizhan R (2018) Malic acid production from biodiesel derived crude glycerol using morphologically controlled Aspergillus niger in batch fermentation. Bioresour Technol 269:393-399. https://doi.org/10.1016/j.biortech. 2018.09.002

Kubicek C, Schreferl-Kunar G, Wöhrer W, Röhr M (1988) Evidence for a cytoplasmic pathway of oxalate biosynthesis in Aspergillus niger. Appl Environ Microbiol 54:633-637

Kumaran P, Hephzibah D, Sivasankari R, Saifuddin N, Shamsuddin AH (2016) A review on industrial scale anaerobic digestion systems deployment in Malaysia: opportunities and challenges. Renew Sust Energ Rev 56:929-940. https://doi.org/10.1016/j.rser.2015.11. 069

Leoneti AB, Aragão-Leoneti V, De Oliveira SVWB (2012) Glycerol as a by-product of biodiesel production in Brazil: alternatives for the use of unrefined glycerol. Renew Energy 45:138-145. https://doi.org/ 10.1016/j.renene.2012.02.032

Liu L, Zhu Y, Li J, Wang M, Lee P, Du G, Chen J (2012) Microbial production of propionic acid from propionibacteria: current state, challenges and perspectives. Crit Rev Biotechnol 32:374-381. https://doi.org/10.3109/07388551.2011.651428

López JÁS, Santos MÁM, Pérez AFC, Martín AM (2009) Anaerobic digestion of glycerol derived from biodiesel manufacturing. Bioresour Technol 100:5609-5615. https://doi.org/10.1016/j. biortech.2009.06.017

Luo G, Xie L, Zhou Q, Angelidaki I (2011) Enhancement of bioenergy production from organic wastes by two-stage anaerobic hydrogen and methane production process. Bioresour Technol 102:8700 8706. https://doi.org/10.1016/j.biortech.2011.02.012

Marshall A, Haverkamp R (2008) Production of hydrogen by the electrochemical reforming of glycerol-water solutions in a PEM 
electrolysis cell. Int J Hydrog Energy 33:4649-4654. https://doi.org/ 10.1016/j.ijhydene.2008.05.029

Martínez-Campos R, de la Torre M (2002) Production of propionate by fed-batch fermentation of Propionibacterium acidipropionici using mixed feed of lactate and glucose. Biotechnol Lett 24:427-431. https://doi.org/10.1023/A:1014562504882

Mulinari J, Venturin B, Sbardelotto M, Dall Agnol A, Scapini T, Camargo AF, Baldissarelli DP, Modkovski TA, Rossetto V, Dalla Rosa C, Reichert FW, Golunski SM, Vieitez I, Vargas GDLP, Dalla Rosa C, Mossi AJ, Treichel H (2017) Ultrasound-assisted hydrolysis of waste cooking oil catalyzed by homemade lipases. Ultrason Sonochem 35:313-318. https://doi.org/10.1016/j.ultsonch.2016.10. 007

Munir E, Yoon JJ, Tokimatsu T, Hattori T, Shimada M (2001) A physiological role for oxalic acid biosynthesis in the wood-rotting basidiomycete Fomitopsis palustris. Proc Natl Acad Sci 98:11126-11130. https://doi.org/10.1073/pnas.191389598

Nuchdang S, Phalakornkule C (2012) Anaerobic digestion of glycerol and co-digestion of glycerol and pig manure. J Environ Manag 101:164-172. https://doi.org/10.1016/j.jenvman.2012.01.031

Pachapur VL, Kutty P, Brar SK, Ramirez AA (2016) Enrichment of secondary wastewater sludge for production of hydrogen from crude glycerol and comparative evaluation of mono-, co-and mixed-culture systems. Int J Mol Sci 17:92. https://doi.org/10.3390/ ijms 17010092

Panpong K, Srisuwan G, Sompong O, Kongjan P (2014) Anaerobic codigestion of canned seafood wastewater with glycerol waste for enhanced biogas production. Energy Procedia 52:328-336. https:// doi.org/10.1016/j.egypro.2014.07.084

Papanikolaou S, Fakas S, Fick M, Chevalot I, Galiotou-Panayotou M, Komaitis M, Marc I, Aggelis G (2008) Biotechnological valorisation of raw glycerol discharged after bio-diesel (fatty acid methyl esters) manufacturing process: production of 1, 3propanediol, citric acid and single cell oil. Biomass Bioenergy 32: 60-71. https://doi.org/10.1016/j.biombioe.2007.06.007

Przystałowska H, Lipiński D, Słomski R (2015) Biotechnological conversion of glycerol from biofuels to 1, 3-propanediol using Escherichia coli. Acta Biochim Pol 62. https://doi.org/10.18388/ abp.2014_885

Pullammanappallil PC, Chynoweth DP, Lyberatos G, Svoronos SA (2001) Stable performance of anaerobic digestion in the presence of a high concentration of propionic acid. Bioresour Technol 78: 165-169. https://doi.org/10.1016/S0960-8524(00)00187-5

Razaviarani V, Buchanan ID (2015) Anaerobic co-digestion of biodiesel waste glycerin with municipal wastewater sludge: microbial community structure dynamics and reactor performance. Bioresour Technol 182:8-17. https://doi.org/10.1016/j.biortech.2015.01.095

Serrano A, Siles JA, Chica AF, Martin MA (2014) Improvement of mesophilic anaerobic co-digestion of agri-food waste by addition of glycerol. J Environ Manag 140:76-82. https://doi.org/10.1016/j. jenvman.2014.02.028

Shah P, Chiu F-S, Lan JC-W (2014) Aerobic utilization of crude glycerol by recombinant Escherichia coli for simultaneous production of poly 3-hydroxybutyrate and bioethanol. J Biosci Bioeng 117:343350. https://doi.org/10.1016/j.jbiosc.2013.08.018

Silva FMS, Mahler CF, Oliveira LB, Bassin JP (2018) Hydrogen and methane production in a two-stage anaerobic digestion system by co-digestion of food waste, sewage sludge and glycerol. Waste Manag 76:339-349. https://doi.org/10.1016/j.wasman.2018.02.039

Silvestre G, Fernández B, Bonmatí A (2015) Addition of crude glycerine as strategy to balance the $\mathrm{C} / \mathrm{N}$ ratio on sewage sludge thermophilic and mesophilic anaerobic co-digestion. Bioresour Technol 193:377385. https://doi.org/10.1016/j.biortech.2015.06.098

Tiehm A, Nickel K, Zellhorn M, Neis U (2001) Ultrasonic waste activated sludge disintegration for improving anaerobic stabilization. Water Res 35:2003-2009. https://doi.org/10.1016/S0043-1354(00)00468-

Valcke D, Verstraete W (1983) A practical method to estimate the acetoclastic methanogenic biomass in anaerobic sludges. J Water Pollut Control Fed:1191-1195

Weemaes MP, Verstraete WH (1998) Evaluation of current wet sludge disintegration techniques. J Chem Technol Biotechnol 73:83-92

Weiland P (2008) Wichtige Messdaten für den Prozessablauf und Stand der Technik in der Praxis. Gülzower Fachgespräche 27:17-31

Yadvika S, Sreekrishnan TR, Kohli S, Rana V (2004) Enhancement of biogas production from solid substrates using different techniquesa review. Bioresour Technol 95:1-10. https://doi.org/10.1016/j. biortech.2004.02.010

Zhang A, Yang S-T (2009) Propionic acid production from glycerol by metabolically engineered Propionibacterium acidipropionici. Process Biochem 44:1346-1351. https://doi.org/10.1016/j.procbio. 2009.07.013

Publisher's note Springer Nature remains neutral with regard to jurisdictional claims in published maps and institutional affiliations. 